\title{
Introduction: Texts and Theories of Travel
}

\author{
SHANG WU
}

Stories and accounts of travel have existed for centuries ever since people started to travel. But it was not until the past few decades that studies of travel and travel writing gained academic attention. Edward Said's Orientalism is often regarded as the critical pioneering work concerning travel writing. Orientalism, published in 1978, "was the first work of contemporary criticism to take travel writing as a major part of its corpus, seeing it as a body of work which offered particular insight into the operation of colonial discourses" (Hulme and Youngs 2002: 8). This development was later termed "postcolonialism" or "postcolonial studies". It is, though, noteworthy that back then travel writing was not considered the subject of focus, rather it was a crucial form of historical representation. Broadly, the intention of such an approach was to recognise and then contest the aftermath of European colonialism in the nineteenth and early twentieth centuries, and to overthrow the hegemonic idea that European identity is always superior to the non-European (Said 2016: 7). In the wake of Orientalism, a wave of scholars initiated the groundwork of travel writing by starting to scrutinise representations of other cultures through the prism of ideologies (see Hulme 1986; Campbell 1988; Pratt 1992; Spurr 1993; Buzard 1993). These scholars reveal that travel narratives are never innocent factual accounts but constructed and situated representations of economic and ideological power relations. As Tim Youngs concludes, "travellers have already been influenced, before they travel, by previous cultural representations that they have encountered. Thus, they never look on places anew or completely independently but perceive them instead through an accretion of others' accounts" (2013: 9). Another impulse behind the recent burgeoning of academic attention to travel writing has been brought by the second-wave of feminism, which dismantles patriarchal ideologies and demands gender equality (Bassnett 2002: 226; Thompson 2011: 3). To confront a maleauthored history, scholars of history and literature started to investigate women travel writers previously overshadowed by men to "demonstrate the contextually and historically specific nature of gender conditions" (Foster and Mills 2002: 1). Both within and outside the colonial context, whether and how women travellers write differently from men (see Robinson 1990; Mills 1991; Morgan 1996; Foster and Mills 2002; Birkett 2004) and the treatment of gender in travel narratives (see Ghose 1998; Youngs 2013; Saunders 2014) 
are two significant and interesting subjects. Subsequent to the wave of postcolonialism and feminism, travel writing studies today has grown beyond the blanket coverage of anatomies of power and become interdisciplinary, theoretically diversified, regionally and temporally nuanced. For example, Susan Morgan, in her book on Victorian women's travel writing about Southeast Asia, highlights the importance of regional and temporal specificity and points out that there is "no bare-bones British Victorian imperialism". (1996: 9) Steve Clark, in Asian Crossings, also notes the significance of a contextualised approach: "Said's initial thesis of a monolithic Western will-topower is almost entirely based on the Near East, with little consideration of the markedly different practices of British colonialism in India, let alone the complex and diverse European relations with Eastern Asia” (2008: 11). And more recently, Translation Studies has brought another dimension to travel writing that entails both cultural and linguistic translation (Hulme and Youngs 2002: 9). A two-way metaphor is often foregrounded - the translator as traveller and the traveller as translator (See Cronin 2000; Duncan and Gregory 2002; Bassnett 2004; Polezzi 2006; Pickford 2019). Sharing a similar role within a liminal space between linguistic and cultural borders, traveller and translator both "relay the new through the known, the unfamiliar in terms of the familiar" and have the potential to deceive as well as to mediate (Polezzi 2006: 171).

Embracing the heterogeneous nature of travel and the studies of travel, the thematic cluster intends both to review developed theoretical perspectives, such as postcolonial conditions and women in travel stories, and to explore possible new areas, such as the relationship between travel and translation. Contributors with different geographical and academic backgrounds engage with theories, histories, narratives, stories and translations of travel, based on different geographical zones and historical contexts.

The literariness of writing travel has always been a recurrent motif. Composing travel is in itself a heuristic journey. Travellers write what they see and see what they expect to see. Jean Bessière, in "Voir ce que je vois, voir ce que je m'attends à voir: degré zéro de l'écriture du voyage et écriture littéraire du voyage. En citant Henri Michaux et Michel Butor", elaborates on "the mimesis of the questioning" which characterises travel writing as literary, with Michaux's and Butor's travels abroad and travel writings as references. Bessière explores the intricacies of writing travel through a list of aphoristic paradoxes: reflexive and not, mediated and not, meta and not, objective and not, implicit and not, which are of great importance for further theoretical discussion.

The connection between travel and translation is complex. As both travel writing and translation are constructed, the translation of travel texts then implies at least two-layers of constructedness. Through translation, the travel 
narrative is reshaped in different linguistic and cultural contexts for another readership. And a particularly interesting case appears when the travel account is translated into the language of the land to which the traveller travelled. In "Travelling back via Translation: Alai, Lijiang and Minority Literature", Duncan Poupard looks into the "back-translation" of a travel account of the city of Lijiang in southwestern China. The original travel narrative written by Alai is composed in Chinese, which is then translated back into the local language, the minority Naxi language of Lijiang using Dongba pictographs. Poupard observes that through such techniques as back-translation, minority cultural specifics are reintroduced and the power to speak is reclaimed. Another major connection between travel writing and translation comes from the translational fabric within travel narrative. In "Writing Travel as Janus: Cultural Translation as Descriptive Category for Travel Writing”, Shang Wu reinvents the contested yet promising concept of cultural translation to analyse the traveller in a liminal space as Janus-faced: one side facing backward to his/her own cultural context and home audience producing translation as product, and the other side facing forward to the foreign land and cultural context going through translation as process. The American writer Peter Hessler's travel book on China Country Driving is cited to illustrate the theoretical framework.

Stories of travel, or tales of quests, not only recount fictionalised journeys but also mirror journeys of self-realisation. Xiuguo Huang's "A Comparative Study of the Womanland in Journey to the West and Flowers in the Mirror" works on imaginary journeys to the female-dominated societies in two traditional Chinese literary works. Through a detailed comparison, Huang argues that although the satirical depictions of the two different 'Womanlands' reflect the authors' denunciation of the oppressive and unequal treatment of women in feudal China, they are in essence still dominated by androcentrism and patriarchalism.

Postcolonial theory is not only used by scholars and critics to read the colonial and postcolonial conditions of travel writing, but is also integrated by some literary practitioners to write about travel. While mediating the gaps between theory and practice, such narratives also better reveal the ambivalence and contradiction of the postcolonial mindset. In "Ethnic Trauma in the Traveler's Eyes: On Naipaul's The Masque of Africa, including a Comparison with Bi Shumin's 30,000 Miles of Africa”, Quan Wang explores the possible reasons for Naipaul's pessimistic convictions about post-apartheid South Africa: the biased Western "modes of thought" and the selected encounters with local "elites". A comparison with another travel account on South Africa by Chinese writer Bi Shumin is conducted as supplementary evidence. 
Finally, Jonathan Locke Hart, in "Violence and Movement: Conflict, Genocide and the Darker Side of 'Travel', looks into the darkness travel contains from a historical perspective. Although in modern days the experience of travel is often presented as self-exploration and spiritual-elevation, we need to not forget the kind of travel that entails violence and death. Hart concentrates mainly on the Norse voyages to Greenland and Vinland, including encounters with the Skrælings in the New World, in The Saga of Vinland, and more briefly on works by Columbus and Bartolomé de Las Casas concerning Spanish violence towards the Natives in the western Atlantic and on Nazi brutality and the Holocaust. Travel in this sense, although ambivalent with occasional tender moments, is "an ordeal, an invasion, a conflict or a death march". Hart eloquently concludes that with the pursuit of travel we also pursue the truth, asymptotic and never-ending.

It is a great honour to co-edit the thematic cluster on travel literature with Jonathan Locke Hart, with gratitude to Jüri Talvet and Katre Talviste at Interlitteraria. It is our hope that the cluster will make its own contribution to the study of travel writing and will serve as a spur to further research and scholarship.

\section{References}

Bassnett, S. 2002. Travel Writing and Gender. - P. Hulme, T. Youngs, eds., The Cambridge Companion to Travel Writing. Cambridge: Cambridge University Press, 225-241. https://doi.org/10.1017/CCOL052178140X.014

Bassnett, S. 2004. Travelling and translating. - World Literature Written in English, 40:2, 66-76. https://doi.org/10.1080/17449850408589391

Birkett, D. 2004. Off the Beaten Track: Three Centuries of Women Travellers. London: National Portrait Gallery.

Buzard, J. 1993. The Beaten Track: European Tourism, Literature, and the Ways to 'Culture', 1800-1918. Oxford: Oxford University Press.

Campbell, M. B. 1988. The Witness and the Other World: Exotic European Travel Writing 400-1600. Cornell University Press.

Clark, S. 2008. Introduction. - S. Clark, P. Smethurst eds., Asian Crossings: Travel Writing on China, Japan and Southeast Asia. Hong Kong: Hong Kong University Press, 11-23.

Cronin, M. 2000. Across the Lines: Travel, Language, Translation. Cork: Cork University Press.

Duncan, J., Gregory, D., eds. 2002. Writes of Passage: Reading Travel Writing. New York: Routledge.

Foster, S., Mills, S., eds. 2002. An Anthology of Women's Travel Writings. Manchester: Manchester University Press. 
WU

Ghose, I. 1988. Women Travellers in Colonial India: The Power of the Female Gaze. Delhi: Oxford University Press.

Hulme, P. 1986. Colonial Encounters: Europe and the Native Caribbean, 1492-1797. London and New York: Methuen.

Hulme, P., Youngs, T. 2002. Introduction. The Cambridge Companion to Travel Writing, Peter Hulme and Tim Youngs, eds., Cambridge: Cambridge University Press, 1-13. https://doi.org/10.1017/CCOL052178140X.001

Mills, S. 1991. Discourses of Difference: An Analysis of Women's Travel Writing and Colonialism. London and New York: Routledge.

Morgan, S. 1996. Place Matters: Gendered Geography in Victorian Women's Travel Books about Southeast Asia. New Brunswick: Rutgers University Press.

Pickford, S. 2019. Travel Writing. - M. Baker, G. Saldanha, eds., Routledge Encyclopedia of Translation Studies. London and New York: Routledge, 606-610.

Polezzi, L. 2006. Translation, Travel, Migration. The Translator, 12(2), 169-188. https:// doi.org/10.1080/13556509.2006.10799214

Pratt, M. L. 1992. Imperial Eyes: Travel Writing and Transculturation. London New York: Routledge.

Robinson, J. 1990. Wayward Women: A Guide to Women Travellers. Oxford: Oxford University Press.

Said, E. W. 2016. Orientalism: Western Conceptions of the Orient. London: Penguin UK.

Saunders, C., ed. 2014. Women, Travel Writing and Truth. London: Routledge.

Spurr, D. 1993. The Rhetoric of Empire: Colonial Discourse in Journalism, Travel Writing, and Imperial Administration. Durham and London: Duke University Press.

Thompson, C. 2011. Travel Writing. London and New York: Routledge.

Youngs, T. 2013. The Cambridge Introduction to Travel Writing. New York: Cambridge University Press. 